\title{
SPATIAL VARIABILITY OF SNOW-PACK OUTFLOW AT A SITE IN SIERRA NEVADA, U.S.A.
}

\author{
by \\ Richard Kattelmann \\ (Center for Remote Sensing and Environmental Optics/CSL, University of California, \\ Santa Barbara, CA 93106, U.S.A.)
}

\section{ABSTRACT}

Water flow through natural snow-packs is generally accepted to be extremely variable even over short distances. Differences in snow properties, and discontinuities in the horizontal and vertical structures of snow-packs, are responsible for variations in the effective area of the snow surface associated with outflow from a part of the base of the snow-pack. At the Central Sierra Snow Laboratory snow-pack outflow has been monitored using four snow-melt lysimeters of $6 \mathrm{~m}^{2}$ area each; two of these collectors were subdivided into three sections of equal area.

Substantial variations in daily and monthly outflow volumes were noted between the individual collectors and also to a greater degree between the $2 \mathrm{~m}^{2}$ sub-units of the divided containers. The relative collecting efficiency of the snow-melt lysimeters also changed over time. In the deep warm snow-packs of the Sierra Nevada forest zone, snow-pack water routing appears to be highly variable, and this variability is on a much larger scale than was previously recognized. The large differences in snow-pack outflow measured in this study suggest that structural discontinuities and microtopography of snow strata can redirect percolating water over an area of several square meters.

\section{INTRODUCTION}

A wide variety of observational evidence has been accumulated in the past four decades which demonstrates that water movement through natural snow cover is not uniform. Application of dye to wet snow clearly shows that water tends to become concentrated in vertical channels and at snow-layer interfaces (Gerdel, 1949, 1954; Langham, 1974). Detailed descriptions of snow-pack structure document inhomogeneities due to the localized presence of water (Seligman, 1936; Sharp, 1951; Wakahama, 1968).

Large discrepancies between calculated snow-melt and snow-pack outflow measured with snow-melt lysimeters also illustrate the non-uniform nature of water flow through snow (Price, 1977; Jordan, 1983; Beaudry, 1984). Uncertainty about the surface area contributing water to a snow-melt lysimeter was noted even with a collector area of $56 \mathrm{~m}^{2}$ (Rockwood and others, 1954). Location of snow lysimeters, as it relates to flow-routing features within different parts of a snow-pack, influences their collecting characteristics. In a study using collectors of area $1 \mathrm{~m}^{2}$, installed at different levels below the snow surface, the volumes of water captured at depths less than $0.4 \mathrm{~m}$ were equal to the calculated snow melt (Jordan, 1983), although the volume of water collected at $1 \mathrm{~m}$ depth was $50 \%$ greater than the calculated snow melt. The amount of water collected by a funnel with an area of only $0.17 \mathrm{~m}^{2}$ located $2.5 \mathrm{~m}$ below the snow surface and underneath a prominent ice layer was the same as the volume of snow melt measured from surface ablation (Colbeck, 1976). In addition to these anomalies, snow-melt lysimeters may sometimes be bypassed completely by the flow field (Tsiouris and others, 1985).
Although snow-melt lysimeters have been installed at dozens of sites around the world, replication of the data from independent collectors and measurement systems has rarely been achieved. Results from the few replicate installations provide some indicators of flow variability in different situations. In a deep snow-pack in coastal British Columbia, three collectors of area $1 \mathrm{~m}^{2}$ were installed $1.5 \mathrm{~m}$ below the surface and $5 \mathrm{~m}$ apart, and five collectors of area $11 \times 10^{-3} \mathrm{~m}^{2}$, were installed $0.6 \mathrm{~m}$ below the surface over a horizontal distance of $5 \mathrm{~m}$ (Wankiewicz, 1976). Over periods of less than $12 \mathrm{~h}$ the coefficient of variation (standard deviation/mean) for the large collectors averaged 0.52 , and for the small snow-melt lysimeters it was 0.66 (Wankiewicz, 1983). Identical snow-melt lysimeters of $4.5 \mathrm{~m}^{2}$ area at two sites with a shallow snow cover in Norway collected approximately equal amounts of water (Harstveit, 1984).

Only rarely has a set of snow-melt lysimeters been designed expressly to assess the variability of water flow through an Arctic snow-pack (Marsh and Woo, 1985). This set included collectors with areas of 1 and $0.25 \mathrm{~m}^{2}$, and a second $0.25 \mathrm{~m}^{2}$ collector which was divided into 16 independently measured cells, each of which was $15 \times 10^{-3} \mathrm{~m}^{2}$ in area. Daily volumes from the three snow-melt lysimeters were always within $10 \%$ of each other, suggesting that flow may be relatively uniform over areas exceeding $0.25 \mathrm{~m}^{2}$ (Marsh and Woo, 1985). However, daily volumes collected from the small compartments of the subdivided container varied from 0 to $240 \%$ of the mean of the total collected volume. Variability between the small compartments was found to be greatest on days with low flow and least on days with higher flow, and information about the distribution of flow over the area was used to develop a routing model of movement of water through snow (Marsh and Woo, 1985). An additional study compared the seasonal snow-melt volumes from six snow-melt lysimeters of area $0.05 \mathrm{~m}^{2}$ with the snow-melt volume from one collector $5 \mathrm{~m}^{2}$ area (Barry and Price, 1987). Total outflow from the large snow-melt lysimeter was the same as the sum of measured snow water equivalent at the onset of melt and rain during the melt period, and was equal to $2.8 \times 10^{-3} \mathrm{~m}$. The mean of seasonal volumes from the six small collectors had a value of $6.2 \times 10^{-3} \mathrm{~m}$ and this was more than twice the value for the large container. Similarly, the highest volume from one of the group of six small collectors was more than twice the lowest volume from the same group. The coefficient of variation for the small snow-melt lysimeters at this stage was calculated as 0.4 ; an even greater variability was noted in the early part of the season.

The investigations outlined above suggest that water movement through snow may be considered to be uniform over areas greater than $0.25 \mathrm{~m}^{2}$ in snow-packs developed under very cold temperatures but to remain variable over areas larger in warm snow-packs. Identification of the scale at which snow-pack properties relating to water movement can be averaged is important in the development and application of simulation models of snow-melt percolation (Colbeck, 1979; Wankiewicz, 1979; Marsh and Woo, 1985) and in the design of sampling procedures for snow-chemistry studies (Barry and Price, 1987). A rule of 


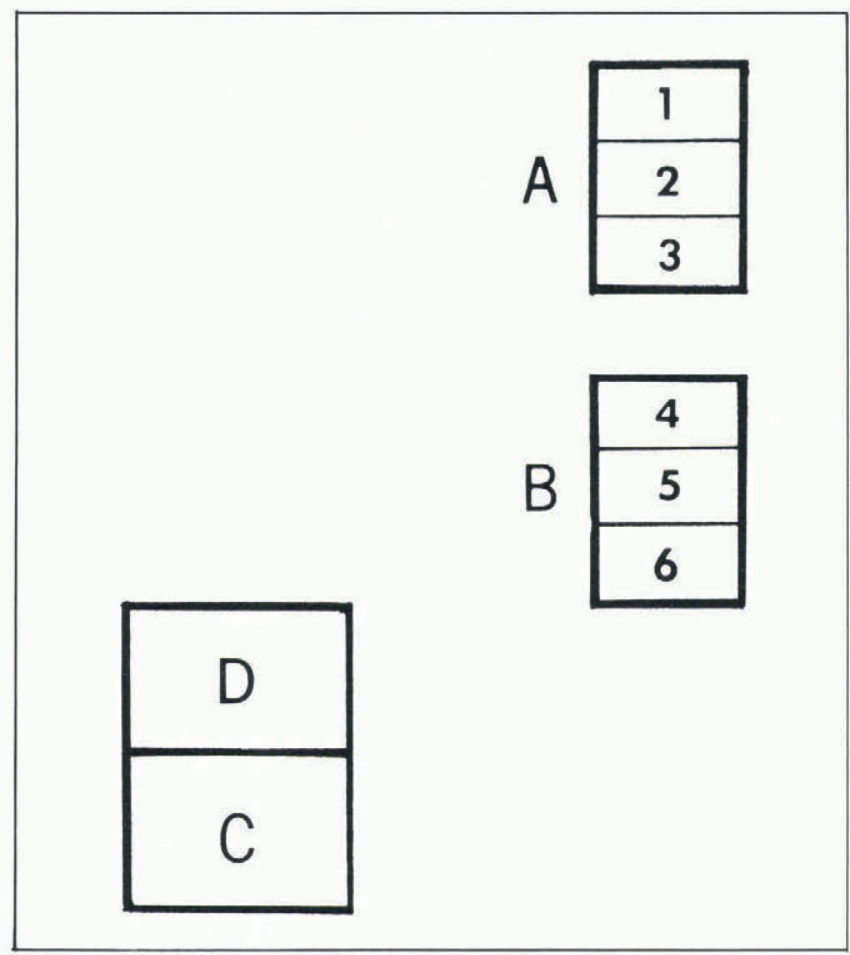

Fig. 1. Two of the four $6 \mathrm{~m}^{2}$ collectors (A-D) at CSSL were subdivided into thirds $(1-6)$.

thumb suggests that water flow is uniform over areas whose size is greater than the square of the snow depth (Male and Gray, 1981); however, except for the studies mentioned above, little quantitative information exists about the variations of water movement in snow (Colbeck, 1979; Colbeck and others, 1979; Marsh and Woo, 1985). This study describes the variation in snow-pack outflow found at a site in the Sierra Nevada of California.

\section{STUDY AREA AND METHODS}

All measurements were made in a 0.5 ha forest opening at the Central Sierra Snow Laboratory (CSSL), a facility operated by the U.S. Forest Service Pacific Southwest Forest and Range Experiment Station. The CSSL is located at Soda Springs, California, about $25 \mathrm{~km}$ north-west of Lake Tahoe, at an elevation of $2100 \mathrm{~m}$. Deep seasonal snow-packs accumulate at the site, which also usually receives some midwinter rainfall. Early work on water movement in snow was performed at this site (Rockwood and others, 1951; Gerdel, 1954) and 35 year old records from experiments using the original CSSL snow-melt lysimeter continue to be used for model validation (Colbeck, 1979; Marsh and Woo, 1985).

As part of a series of investigations of snow-pack water movement at the CSSL, snow-pack outflow has been monitored with several snow-melt lysimeters (Kattelmann, 1984). Four snow-melt lysimeters, each $6 \mathrm{~m}^{2}$ in area, were arranged in two pairs (Fig. 1); one pair shared a common wall, the second pair was about $10 \mathrm{~m}$ from the first pair and these two collectors were separated by a distance of $1 \mathrm{~m}$. (Outflow from the area between these two snow-melt lysimeters was also collected and measured.) The second pair of collectors was subdivided into three equal parts, with independent plumbing and measurement equipment for each sub-area of $2 \mathrm{~m}^{2}$. All of these snow-melt lysimeters were of the ground-based, unenclosed type with rims at least $150 \mathrm{~mm}$ high. Outflow from each collector was piped to an independent tipping bucket that tipped at volumes equivalent to about $0.5 \mathrm{~mm}$ above the area of the collector. Electrical heat tape extends from each collector drain to the measurement chamber, and this heat tape was activated manually on occasions a few times per season in 1985 and 1986 and automatically for $15 \mathrm{~min} / \mathrm{d}$ in 1987. In 1986 and 1987, pipes extending from a nearby tower into each $2 \mathrm{~m}^{2}$ collector allowed testing of the drain system without the snow cover being disturbed. Tip volumes were recorded on a multi-channel chart recorder and converted to values of $\mathrm{mm} / \mathrm{h}$.

The snow-melt lysimeters were installed in 1983, and mechanical problems discovered during the ensuing winter were remedied in the summer of 1984. The only mechanical difficulties experienced during the three seasons reported here occurred in 1985 when there was leakage around one drain and deformation of one wall between two of the small collectors changed their areas slightly. The undivided large collectors are essentially fail-safe. The only potential problems with the $2 \mathrm{~m}^{2}$ collectors are leakage around the drain and freezing of the drain. Both problems did occur during the test year and also in two of the collectors in 1985. (Data from the group of small collectors that had these failures in 1985 have not been used here.) Recorder problems also caused some loss of data throughout 1985, otherwise results reported here were not believed to be attributes of the outflow collection system. Ground heat at the study site resulted in a relatively consistent basal melt rate of about $0.5 \mathrm{~mm} / \mathrm{d}$ and this process allowed an easy check on snow-melt lysimeter performance during periods

TABLE I. MONTHLY SNOW-PACK OUTFLOW FROM $6 \mathrm{~m}^{2}$ SNOW-MELT LYSIMETERS

Month Snow depth

(m)

$3 / 85 \quad 1.4$

Totals

2.0

$12 / 85$

$1 / 86$

$2 / 86$

$3 / 86$

$4 / 86$

$5 / 86$

Totals

Totals

2.4

2.1

1.2
Snow-melt lysimeter

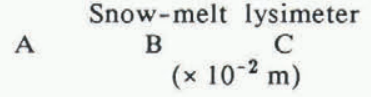

D

18

70

68

36

90

43

88

12
23
66

66

80

85

361

$$
\text { Mean }
$$$$
\left(\times 10^{-2} \mathrm{~m}\right)
$$

$\begin{array}{rrr}16 & 8.0 & 0.50 \\ 58 & 19.1 & 0.33\end{array}$

$\begin{array}{rrr}10 & 1.8 & 0.18 \\ 18 & 3.9 & 0.22 \\ 43 & 17.0 & 0.40 \\ 50 & 21.6 & 0.43 \\ 62 & 17.7 & 0.29 \\ 83 & 8.4 & 0.10\end{array}$


without surface-water input. There was no evidence of the sudden drainage of water that would be expected following the thawing of a frozen drain.

\section{RESULTS AND DISCUSSION}

The mean, standard deviation, and coefficient of variation were calculated for the $6 \mathrm{~m}^{2}$ collectors for all months with a recorded average outflow greater than $100 \mathrm{~mm}$ (Table I). Coefficients of variation ranged from 0.2 to 0.5 in the months January-March, and declined in April and May. This decline in variability towards the end of the melt season may have been due to any or all decreasing snow depth, break-down of ice layers, and decreasing importance of flow through vertical channels relative to flow through the entire snow-pack. Variations in daily outflow were occasionally much greater than the monthly values.

For three of the snow-melt lysimeters, monthly snow-melt volumes were generally similar and annual volumes for 1986 and 1987 were within $15 \%$ of each other. However, volumes collected by the fourth collector were in general much greater than the mean for the other three. This fourth collector is located on level ground $4 \mathrm{~m}$ away from the foot of a short $5^{\circ}$ slope; this slight slope persisted in the snow strata leading to the collector. A shallow slope in the snow was also observed to form towards the opposite direction over the adjacent (southern) collector due to partial shading by the forest margin. Snow over the northern collector received slightly more solar energy than did snow over the southern one and it therefore tended to settle and melt to a greater extent than did the snow immediately to the south. A minor depression formed in the snow at the junction of these slight slopes; this depression happened to be over a collector ( $D$ in Table $\mathrm{I}$ ) that consequently received a greater volume of water than the three other collectors and was usually the first one to respond to any inputs of water at the snow surface. This example illustrates the potential effects of microtopography and radiation influences on water routing in snow.

Variability in measured snow-pack outflow was much greater between the $2 \mathrm{~m}^{2}$ sub-units than between the individual $6 \mathrm{~m}^{2}$ collectors. The standard deviation (SD) of ten exceeded the mean on a daily basis when flows were in excess of $10 \mathrm{~mm} / \mathrm{d}$. Variability was greatest during intense rain events on moderately deep snow (Table II). During the February 1986 rainstorm, the highest and lowest volumes differed by a factor of 50 . Outflow from early season rain events on shallow snow (December 1985) or on empty collectors (October 1985) was relatively consistent between collectors. The greater variability with deeper snow suggests that water was being redirected within the snow-pack above the collectors.

Monthly volumes from the $2 \mathrm{~m}^{2}$ collectors (Table III) also indicate greater variation at this smaller scale than was recorded for the $6 \mathrm{~m}^{2}$ collectors, and in all months the coefficients of variation were greater for the smaller collectors than for the larger ones. To simplify comparisons between months, monthly volumes were converted to a proportion of the monthly mean (Table IV). Outflow from any given collector relative to the mean for the small collectors changed considerably from month to month. Monthly volumes were ranked from highest volume (1) to lowest volume (6) (Table V); these rankings changed over each season although position 2 was dominant throughout most of 1986. All of the dramatic changes noted could be associated with distinct changes in the snow-pack, such as addition of a new snow layer, substantial melt, or rainfall. These obvious influences could be assumed to have led to internal changes such as the creation of a new layer interface, creation or abandonment of vertical flow channels, and changes in permeability of ice layers.

\section{TABLE II. OUTFLOW VOLUMES FROM RAIN EVENTS IN $2 \mathrm{~m}^{2}$ COLLECTORS}

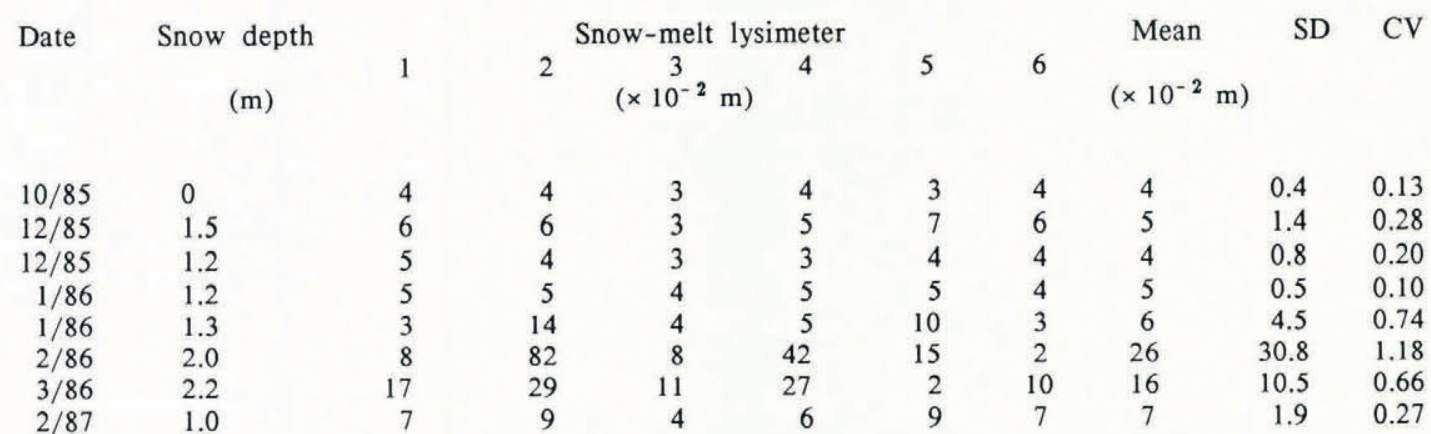

\section{TOTAL III. MONTHLY OUTFLOW VOLUMES FROM $2 \mathrm{~m}^{2}$ COLLECTORS}

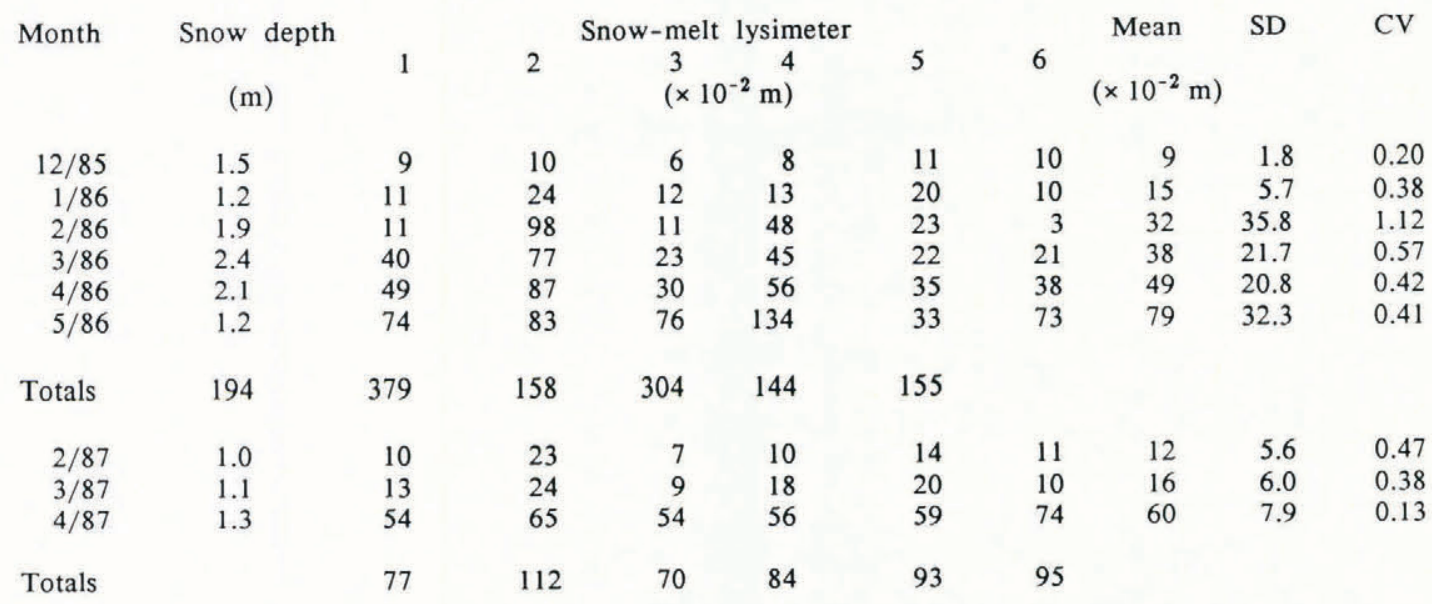


TABLE IV. MONTHLY VOLUMES EXPRESSED AS A PROPORTION OF THE MEAN ( $2 \mathrm{~m}^{2}$ COLLECTORS)

\begin{tabular}{rcccccc} 
Month & \multicolumn{7}{c}{ Snow-melt lysimeter } \\
& 1 & 2 & 3 & 4 & 5 & 6 \\
& & & & & & \\
$12 / 85$ & 1.00 & 1.11 & 0.67 & 0.89 & 1.22 & 1.11 \\
$1 / 86$ & 0.73 & 1.60 & 0.80 & 0.87 & 1.33 & 0.67 \\
$2 / 86$ & 0.34 & 3.06 & 0.34 & 1.50 & 0.72 & 0.09 \\
$3 / 86$ & 1.05 & 2.03 & 0.61 & 1.18 & 0.58 & 0.55 \\
$4 / 86$ & 1.00 & 1.78 & 0.61 & 1.14 & 0.71 & 0.78 \\
$5 / 86$ & 0.94 & 1.05 & 0.96 & 1.69 & 0.42 & 0.92 \\
& & & & & & \\
$2 / 87$ & 0.83 & 1.92 & 0.58 & 0.83 & 1.17 & 0.92 \\
$3 / 87$ & 0.81 & 1.50 & 0.56 & 1.13 & 1.25 & 0.63 \\
$4 / 87$ & 0.90 & 1.08 & 0.90 & 0.93 & 0.98 & 1.23
\end{tabular}

TABLE V. RANK ORDER OF MONTHLY VOLUMES FOR THE $2 \mathrm{~m}^{2}$ COLLECTORS

\begin{tabular}{lllllll} 
Month & \multicolumn{5}{c}{ Snow-melt lysimeter } \\
& 1 & 2 & 3 & 4 & 5 & 6 \\
$12 / 85$ & 4 & 3 & 6 & 5 & 1 & 2 \\
$1 / 86$ & 5 & 1 & 4 & 3 & 2 & 6 \\
$2 / 86$ & 5 & 1 & 4 & 2 & 3 & 6 \\
$3 / 86$ & 3 & 1 & 4 & 2 & 5 & 6 \\
$4 / 86$ & 3 & 1 & 6 & 2 & 5 & 4 \\
$5 / 86$ & 4 & 2 & 3 & 1 & 6 & 5 \\
$2 / 87$ & 4 & 3 & 6 & 5 & 1 & 3 \\
$3 / 87$ & 4 & 1 & 6 & 3 & 2 & 5 \\
$4 / 87$ & 5 & 2 & 6 & 4 & 3 & 1
\end{tabular}

\begin{abstract}
Three snowstorms which occurred in February and March 1985 provided an opportunity for observing water routing through fresh snow layers. Each storm deposited more than a meter of snow and, within $48 \mathrm{~h}$ of the end of each storm, melt water had percolated through the still sub-freezing snow layers and pre-existing snow-pack into the collectors. In each case, the initial melt-water pulse arrived at a different set of snow-melt lysimeters. The relative volumes of snow melt collected varied between the three storms, but in each case the first collectors to respond also captured the most water. These observations indicate that the channel development in the fresh snow delivered water to different regions of the channel network that already existed in the pre-storm snow-pack.
\end{abstract}

\section{SUMMARY AND CONCLUSIONS}

Assuming that there were no undetected adverse influences of the collection system, snow-pack outflow data from our study site in the Sierra Nevada indicate that water flow through natural snow-packs varies spatially on a larger scale than has generally been realized. The standard deviation for the monthly volumes of water intercepted by the six $2 \mathrm{~m}^{2}$ collectors was usually more than $40 \%$ of the mean and variability was of ten much greater on a daily basis. The relative volumes collected by the different snow-melt lysimeters changed over a period of time, apparently in response to changes in the channel network that existed within the snow-pack.

The outflow volumes which were collected over the four areas of $6 \mathrm{~m}^{2}$ were somewhat variable from collector to collector. In this case, differences between collectors were more consistent than differences noted for the smaller collectors and, in the most obvious situation, could be related to microtopography. Even on essentially level ground, shading and drifting can produce subtle slopes in snow layers which redirect water flow and result in non-uniform outflow over areas of several square meters.

Spatial variability of water flow through snow-packs should now be investigated in other snow climates. It is recommended that snow-melt lysimeters should be of greater area than is the current practice, and that they should be replicated in order to assess the validity of results obtained by their use. When additional data about the scale at which water flow through snow can be considered uniform are available from more locations, this information will be useful in modifying both concepts and models of the waterpercolation process.

\section{ACKNOWLEDGEMENTS}

The assistance of B. McGurk, N. Berg, J. Bergman, R. Osterhuber, M. Pack, and K. Younkin in designing, constructing, modifying, and maintaining the snow-melt lysimeters, and in collecting and reducing the data from them is greatly appreciated. Discussions with B. McGurk and D. Azuma improved this manuscript.

\section{REFERENCES}

Barry, P.J. and A.G. Price. 1987. Short term changes in the fluxes of water and of dissolved solutes during snow-melt. In Jones, H.G. and W.J. Orville-Thomas, eds. Seasonal snowcovers: physics, chemistry, hydrology. Dordrecht, etc., D. Reidel Publishing Company, 501-530.

Beaudry, P.G. Unpublished. Effects of forest harvesting on snowmelt during rainfall in coastal British Columbia. (M.F. thesis, University of British Columbia, 1984.)

Colbeck, S.C. 1976. On the use of tensiometers in snow hydrology. J. Glaciol., 17(75), 135-140. 
Colbeck, S.C. 1979. Water flow through heterogeneous snow. Cold Reg. Sci. Tech., 1(1), 37-45.

Colbeck, S.C. and 6 others. 1979. Snow accumulation, distribution, melt, and runoff. Eos, 60(21), 465-468.

Gerdel, R.W. 1949. The storage and transmission of liquid water in the snow pack as indicated by dyes. Proc. West. Snow Conf., 16, 81-91.

Gerdel, R.W. 1954. The transmission of water through snow. Trans. Am. Geophys. Union, 35(3), 475-485.

Harstveit, K. 1984. Snowmelt modelling and energy exchange between the atmosphere and a melting snow cover. Bergen, University of Bergen. Geophysical Institute. Meteorological Division. (Scientific Report 4.)

Jordan, P. 1983. Meltwater movement in a deep snowpack. Water Resour. Res., 19(4), 979-985.

Kattelmann, R.C. 1984. Snowmelt lysimeters: design and use. Proc. West. Snow Conf., 52, 68-79.

Langham, E.J. 1974. The occurrence and movement of liquid water in the snowpack. In Santeford, H.S. and J.L. Smith, eds. Advanced concepts and techniques in the study of snow and ice resources. Washington, DC, National Academy of Sciences, 67-75

Male, D.H. and D.M. Gray. 1981. Snowcover ablation and runoff. In Gray, D.M. and D.H. Male, eds. Handbook of snow; principles, processes, management and use. Toronto, etc., Pergamon Press, 360-436.

Marsh, P. and M.-k. Woo. 1985. Meltwater movement in natural heterogeneous snow covers. Water Resour. Res., 21(11), 1710-1716.

Price, A.G. 1977. Snowmelt runoff processes in a
sub-Arctic area. Montreal, McGill University. (Sub-Arctic Research Paper 29.)

Rockwood, D.M., P.B. Boyer, and C.E. Hildebrand. 1954 Lysimeter studies of runoff from a deep snow pack. International Association of Scientific Hydrology Publication 39 (General Assembly of Rome 1954 - Snow and Ice), 137-165.

Seligman, G. 1963. Snow structure and ski fields. Joseph Adams, Brussels,

Sharp, R.P. 1951. Features of the firn on the upper Seward Glacier, St. Elias Mountains, Canada. J. Geol., 59(6), 599-621.

Tsiouris, S., C.E. Vincent, T.D. Davies, and P. Brimblecombe. 1985. The elution of ions through field and laboratory snowpacks. Ann. Glaciol., 7, 196-201.

Wakahama, G. 1968. The metamorphism of wet snow. International Association of Scientific Hydrology Publication 79 (General Assembly of Bern 1967 - Snow and Ice), 370-379.

Wankiewicz, A. 1979. A review of water movement in snow. In Colbeck, S.C. and M. Ray, eds. Proceedings. Modeling of Snow Cover Runoff. Hanover, NH, Cold Regions Research and Engineering Laboratory, 222-252.

Wankiewicz, A. 1983. Variability of flow within ripe snowpacks. Ottawa, National Hydrology Research Institute.

Wankiewicz, A. Unpublished. Water percolation within a deep snowpack - field investigations at a site on Mt. Seymour, British Columbia. (Ph.D. thesis, University of British Columbia, 1976.) 